\title{
The Effect of Cold-Drawing on the Creep Behavior of a Nickel-4.2 Percent Aluminum Alloy
}

\author{
William D. Jenkins and William A. Willard
}

Institute for Materials Research, National Bureau of Standards, Washington, D.C.

(February 21, 1966)

\begin{abstract}
Creep tests were made at 700,900 , and $1200{ }^{\circ} \mathrm{F}\left(644,755\right.$, and $\left.921{ }^{\circ} \mathrm{K}\right)$ on a nickel-4.2 percent aluminum alloy (Duranickel) initially as cold-drawn and as cold-drawn and age-hardened. Microstructural changes occurring during creep are correlated with the flow, fracture, and ductility of the specimens. Light and electron microscope observations indicate that increases in creep strength were associated with the formation of rather straight discontinuous slip bands, a well defined subgrain structure, small precipitates of $\mathrm{Ni}_{3} \mathrm{Al}$, and a general distribution of these precipitates throughout the grains. Creep strength at $1200{ }^{\circ} \mathrm{F}$ was relatively unaffected by prior cold-drawing or aging. Intercrystalline cracking, accompanied by low ductility, was evident at 900 and $1200^{\circ} \mathrm{F}$ and slow creep rates; whereas transcrystalline cracking and high ductility values were observed at $700{ }^{\circ} \mathrm{F}$.
\end{abstract}

Key Words: Cold-drawing, creep, nickel alloys, Duranickel, nickel-aluminum precipitates, high temperatures, deformation.

\section{Introduction}

A comprehensive investigation designed to evaluate the influence of stress, strain, strain rate, temperature, and structure on the rheological properties of a precipitation-hardening nickel-4.2 percent aluminum alloy (Duranickel*) has been in progress for the last few years at the National Bureau of Standards. The tensile and creep properties of annealed and annealed and aged Duranickel have been previously published $[1,2] .{ }^{1}$ The present phase of the investigation describes (1) the influence of cold-drawing on hardness and creep behavior; (2) the effect of prior aging on creep characteristics; (3) the influence of creep on aging; (4) the role of creep rate and microstructure on crack formation and fracture. In addition, data, previously published [2] describing the temperature dependence of creep behavior of annealed and annealed and aged Duranickel are included for comparison purposes.

\section{Material and Testing Procedure}

The chemical composition of the metal used in this investigation is given in table 1 . All the bars were processed from the same heat as that previously used $[1,2]$ and were supplied by the Huntington Alloy Products Division of the International Nickel Company in the form of $7 / 8$-in. round rods, approximately 15-ft long. The bars were hot-rolled, descaled, and

\footnotetext{
*Trade name International Nickel Company.
}

${ }^{1}$ Figures in brackets indicate the literature references at the end of this paper. annealed at $1725{ }^{\circ} \mathrm{F}\left(1213{ }^{\circ} \mathrm{K}\right)$, then cold-drawn by the manufacturer to give a tensile strength of $127,000 \mathrm{psi}$ and a hardness of 27 Rockwell "C". Specimens, $1 / 4$ in. in length, were cut from the bar and aged in vacuo for $16 \mathrm{hr}$ at temperatures ranging from 700 to $1250{ }^{\circ} \mathrm{F}\left(644\right.$ to $\left.948{ }^{\circ} \mathrm{K}\right)$. The specimens age-hardened above $900{ }^{\circ} \mathrm{F}\left(755^{\circ} \mathrm{K}\right)$ were cooled at a rate of $25^{\circ} \mathrm{F} / \mathrm{hr}$ to $900{ }^{\circ} \mathrm{F}$, then furnace cooled to room temperature.

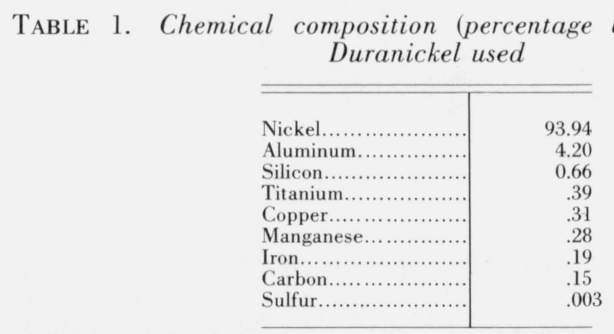

Determinations made at the National Bureau of Standards.

Specimens age-hardened at $900{ }^{\circ} \mathrm{F}$ and below were also furnace cooled. Room-temperature hardness surveys indicated maximum hardness at $1100{ }^{\circ} \mathrm{F}(866$ ${ }^{\circ} \mathrm{K}$ ) was attained with a $16 \mathrm{hr}$ aging time (fig. 1C). Above this temperature at this time the metal appeared to be overaged (fig. 1A). In order to ascertain the effect or rate of cooling on the initial structure and hardness of the cold-drawn metal, specimens were heated in air for $16 \mathrm{hr}$ at temperatures ranging from 700 to $1200{ }^{\circ} \mathrm{F}\left(644\right.$ to $\left.921{ }^{\circ} \mathrm{K}\right)$ and water quenched (fig. 1A). Room temperature hardness surveys indicated the hardness values for each temperature were lower than those obtained by furnace cooling. Another 

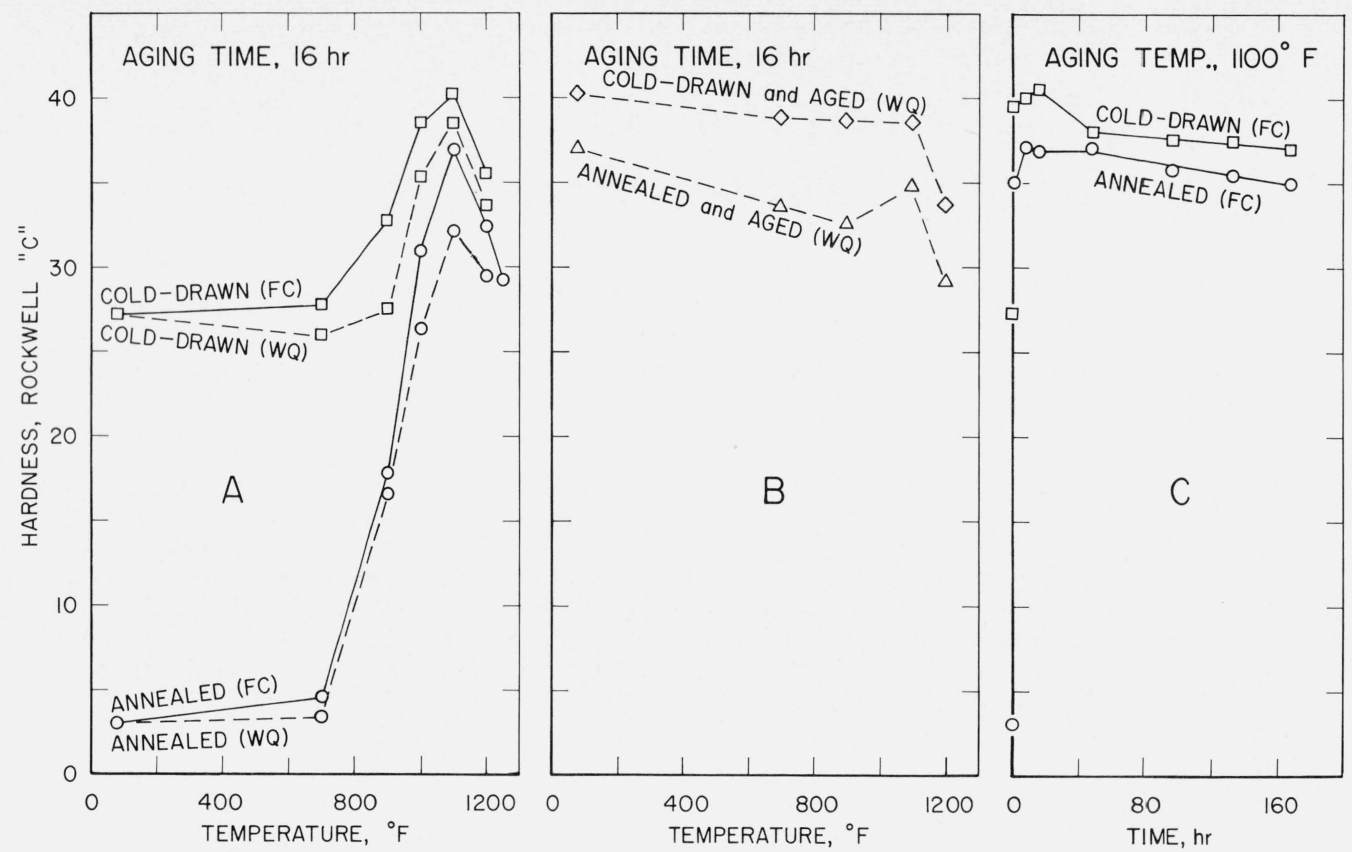

FIGURE 1. Effect of aging temperature and time and rate of cooling on the hardness of Duranickel. FC - furnace cooled; WQ - water quenched.

group of cold-drawn specimens was aged at $1100{ }^{\circ} \mathrm{F}$ for $16 \mathrm{hr}$ and furnace cooled. Then they were heated in air to temperatures of $700,900,1100$, and $1200{ }^{\circ} \mathrm{F}$ and held for $16 \mathrm{hr}$ before water quenching. This procedure was used in order to obtain more stable microstructures in the specimens. Room-temperature hardness values indicated a softening effect for the cold-drawn and aged specimens (fig. 1B). The same general trend was also observed for the annealed and aged specimens (fig. 1B).

Cold-drawn rods were cut into specimens $61 / 4$-in. in length for creep testing. These were divided into two groups: one group to be tested in the cold-drawn condition, the other group to be tested in the aged condition (aged at $1100^{\circ} \mathrm{F}$ for $16 \mathrm{hr}$ and furnace cooled). Room-temperature tensile properties were determined by the authors for the annealed, cold-drawn and aged specimens (table 2).

The creep specimens had a reduced section of 0.252 in. diam over a 2-in. gage length and the ends were

TABLE 2. Room temperature tensile properties of Nickel-4.2 percent aluminum alloy

\begin{tabular}{|c|c|c|c|c|c|c|}
\hline Condition & $\begin{array}{l}\text { Upper } \\
\text { yield } \\
\text { stress }\end{array}$ & $\begin{array}{l}\text { Lower } \\
\text { yield } \\
\text { stress }\end{array}$ & $\begin{array}{c}\text { Yield } \\
\text { strength } \\
(0.2 \% \text { offset })\end{array}$ & $\begin{array}{l}\text { Tensile } \\
\text { strength }\end{array}$ & $\begin{array}{l}\text { Elon- } \\
\text { gation }\end{array}$ & $\begin{array}{l}\text { Reduc- } \\
\text { tion } \\
\text { area }\end{array}$ \\
\hline Annealed.............. & $\begin{array}{l}\text { psi } \\
45,900\end{array}$ & $\begin{array}{l}\text { psi } \\
45,700\end{array}$ & psi & $\begin{array}{l}\text { psi } \\
104,200\end{array}$ & $\begin{array}{r}\text { Percent } \\
47\end{array}$ & $\begin{array}{r}\text { Percent } \\
77\end{array}$ \\
\hline Annealed and aged. & ............ & & 122,200 & 183,000 & 20 & \\
\hline Cold-drawn................... & (a) & & 101,400 & 126,600 & 22 & 65 \\
\hline Cold-drawn and aged.. & & & 145,500 & 188,000 & 18 & 52 \\
\hline
\end{tabular}

machined with $3 / 4$ in. $\times 10$ threads. The reduced section was finished by grinding and then polished in the axial direction, using No. 400 Alumina polishing paper. Before testing, each creep specimen, colddrawn or cold-drawn and aged, was heated in a tube furnace to the desired temperature and equilibrated at temperature for $16 \mathrm{hr}$. It was then tested at temperature under constant load. The creep-rupture machines used were of a multiple lever type with motorized jacks to prevent shock loading. They were recently calibrated at room temperature and the errors for the stresses used were less than 0.5 percent. The temperature of each of the specimens was controlled to an accuracy of $\pm 2{ }^{\circ} \mathrm{F}$. Strain-time data were obtained from electric contact follow-up type extensometers attached to shoulders of the specimens. The sensitivity of extension measurement was approximately 0.00005 in.

\section{Metallography}

Most of the specimens tested to fracture in creep were subjected to a metallographic examination. In general, it was observed that transcrystalline cracks having a round or elliptical shape were predominant at $700{ }^{\circ} \mathrm{F}$. A mixture of transcrystalline and intercrystalline cracks was evident at $900{ }^{\circ} \mathrm{F}$. The intercrystalline cracks were more populous at the slower creep rates. At $1200{ }^{\circ} \mathrm{F}$, the cracks were almost exclusively intercrystalline. 
Four specimens, two each of the annealed and aged and the cold-drawn and aged metal, were selected for a comprehensive metallographic examination after being tested to fracture in creep. The microstructures are shown in figures 2 to 7 . Microstructures of the alloy in the annealed and annealed and aged conditions were previously shown [1].

The basis for selection was (1) these specimens illustrate the effect of cold-drawing on the aged micro- structure; (2) they represent the microstructures associated with the extremes of temperatures used $(700$ and $1200{ }^{\circ} \mathrm{F}$ ); (3) they show the effects of slow creep rates on changes in nicrostructure; and (4) they represent microstructures that differed significantly from those previously shown for fast creep rates [1, 2]. Cracks, formed at $700{ }^{\circ} \mathrm{F}$, are illustrated by the photomicrographs in figure $2 \mathrm{~A}$ and $\mathrm{B}$. Cracks formed at $1200{ }^{\circ} \mathrm{F}$ are shown in figure $2 \mathrm{C}$ and D. More cracks
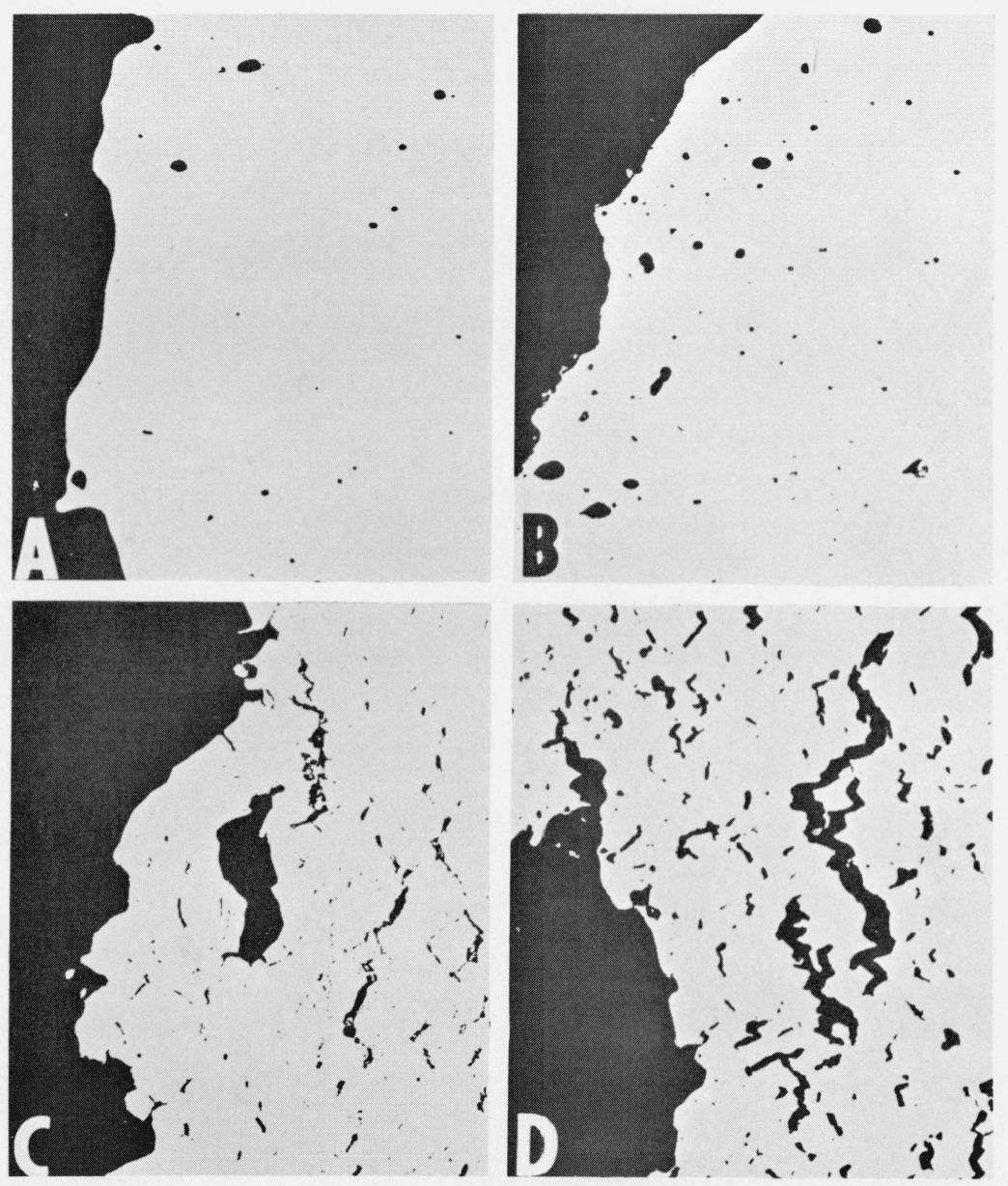

FIGURE 2. Relation of test conditions to number and distribution of cracks in fractured creep specimens.

Longitudinal sections, at axis, near fracture, unetched. $\mathrm{X} 83$.

\begin{tabular}{c|r|c|c}
\hline \hline Condition & $\begin{array}{c}\text { Test } \\
\text { temperature }\end{array}$ & $\begin{array}{c}\text { Fracture } \\
\text { time }\end{array}$ & $\begin{array}{c}\text { Reduction } \\
\text { of area }\end{array}$ \\
\hline A Annealed and & ${ }^{\circ} \mathrm{F}$ & $h r$ & $\%$ \\
aged & 700 & 1367.2 & 5 \\
$\mathrm{~B}$ Cold-drawn \\
and aged \\
$\mathrm{C}$ Annealed and & 700 & 1068 & 13.5 \\
$\begin{array}{c}\text { aged } \\
\mathrm{D} \text { Cold-drawn } \\
\text { and aged }\end{array}$ & 1200 & 2059.7 & 6 \\
\hline
\end{tabular}




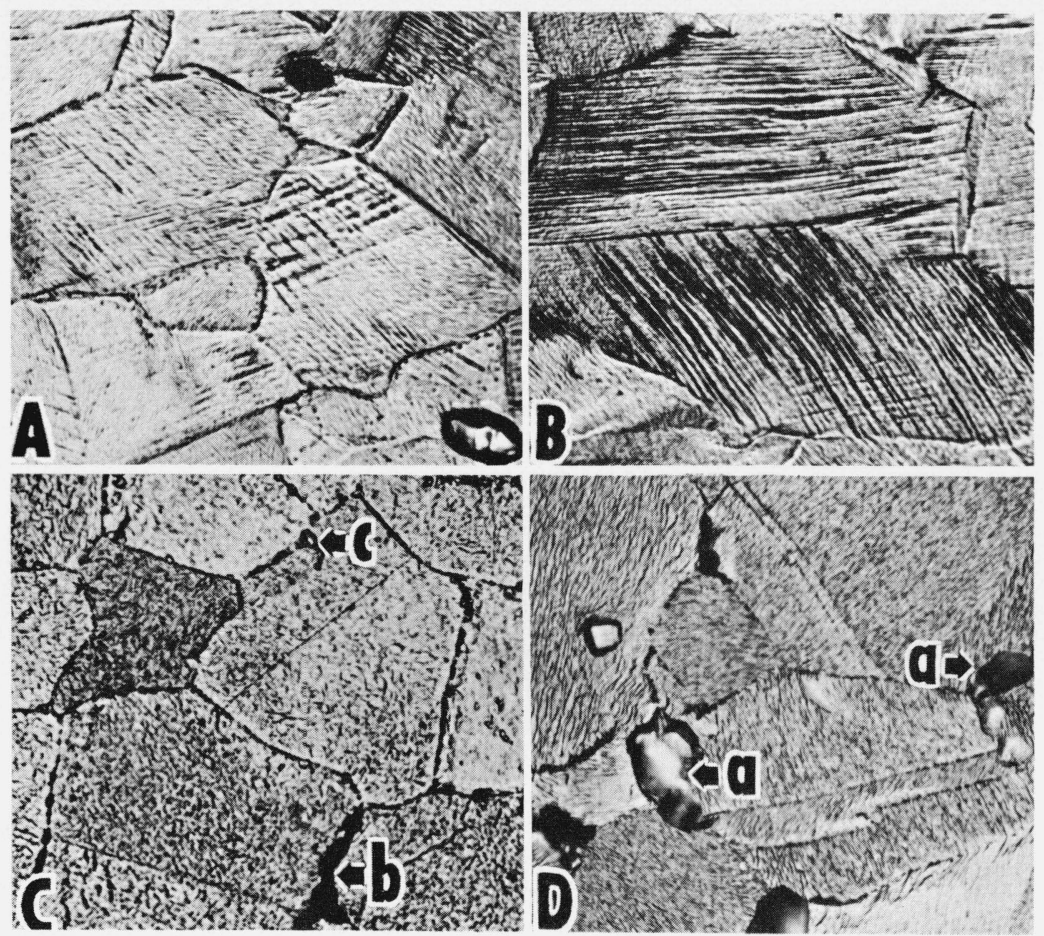

FigURE 3. Relation of test conditions to structures of Duranickel after fracture.

Longitudinal sections, at axis, near fracture. Etched in a solution containing $25 \mathrm{ml}$ each of $\mathrm{HNO}_{3}$, glacial acetic acid, $\mathrm{HCl}$ and water and $3 \mathrm{~g}$ of $\mathrm{NaOH} ; \mathrm{X} 667$. Arrows indicate intercrystalline cracks at "a", "b", and "c".

\begin{tabular}{c|c|c|c}
\hline \hline Condition & $\begin{array}{c}\text { Test } \\
\text { temperature }\end{array}$ & $\begin{array}{c}\text { Fracture } \\
\text { time }\end{array}$ & $\begin{array}{c}\text { Reduction } \\
\text { of area }\end{array}$ \\
\hline A Annealed and & 700 & 1367.2 & $\%$ \\
$\begin{array}{c}\text { aged } \\
\text { B Cold-drawn }\end{array}$ & 700 & 1068 & 13.5 \\
$\begin{array}{c}\text { and aged } \\
C \text { Annealed and } \\
\text { aged }\end{array}$ & 1200 & 2059.7 & 6 \\
$\begin{array}{c}\text { cold-drawn } \\
\text { and aged }\end{array}$ & 1200 & 2452.7 & 6.5 \\
\hline
\end{tabular}

were observed in the specimens that had been coldworked prior to aging. If it is assumed that a greater number of precipitates were initially present in the cold-drawn and aged metal than in the annealed and aged specimens, these additional precipitates could act as sources for the formation of the cracks as illustrated by the models shown in a previous paper [1, figs. 9 and 10]. The effect of cold-drawing prior to aging on the nature of the substructures within the grains of the fractured specimens is shown in figure 3 . Intersecting strain markings were evident in the specimens tested at $700{ }^{\circ} \mathrm{F}$ (fig. $3 \mathrm{~A}$ and $\mathrm{B}$ ); however, a greater number of curved, wavy markings was observed in the cold-drawn and aged metal (fig. 3B), supporting the hypothesis that more precipitates occurred in the cold- drawn metal. Some of the markings did not traverse the grain from one boundary to the other. Precipitates, subgrain boundaries, and slip bands acted as barriers to the continuous motion of dislocations across the grains as will be illustrated later (fig. $5 \mathrm{~A}$ ) by electron microscopy. A fine structure was observed within the grains of specimens tested at $1200{ }^{\circ} \mathrm{F}$ (fig. 3C and D). As will be shown later (figs. 6 and 7) some of this substructure consists of overaged precipitates. Intercrystalline cracks are larger for the cold-drawn and aged specimen (fig. 3Da) than for the annealed and aged specimen (fig. $3 \mathrm{Cb}$ ). Smaller cracks within the vicinity of the precipitates at the grain boundaries (fig. 3Cc) indicate that voids are nucleated first in these regions, then coalesce to form holes and cracks. 

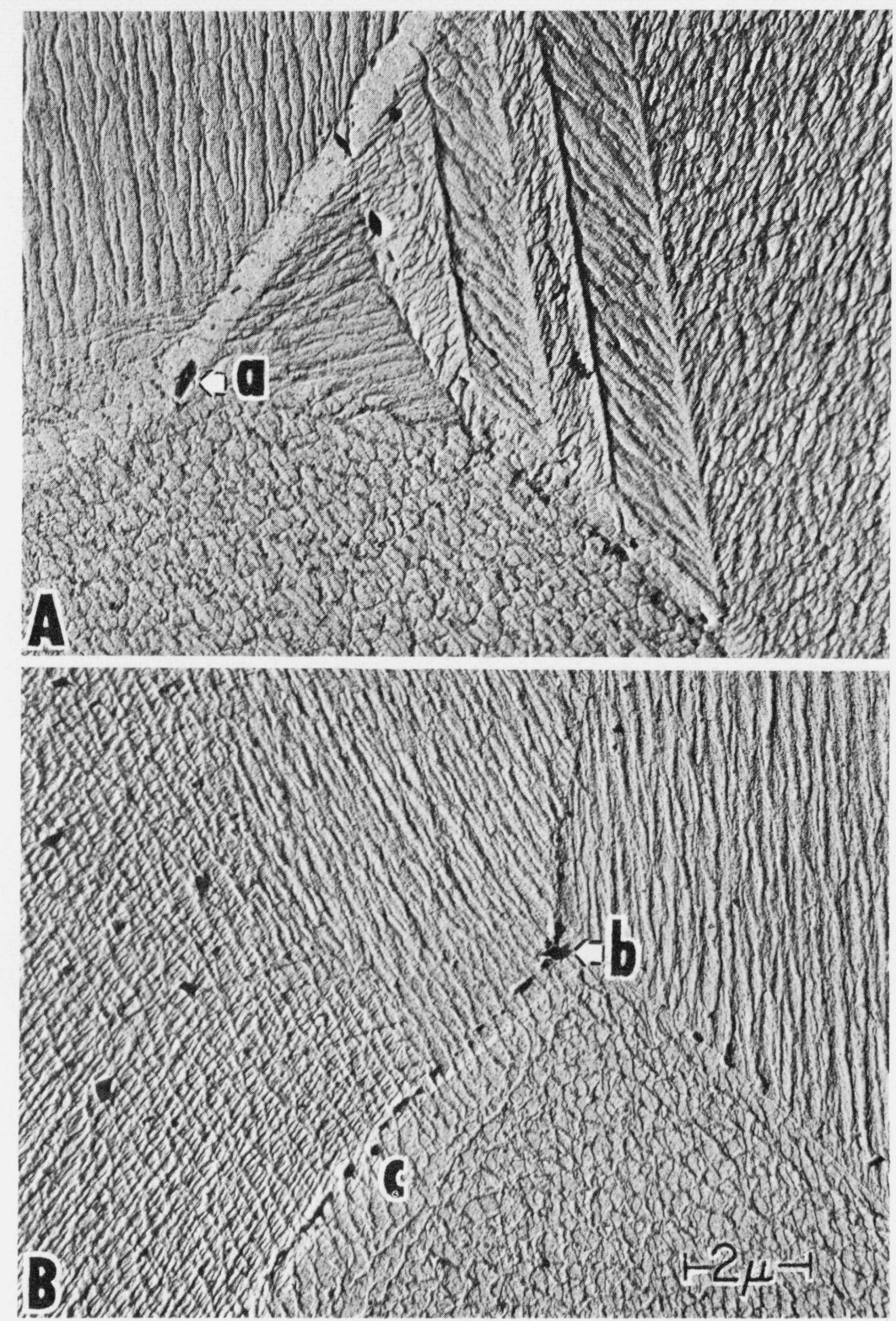

FIGURE 4. Electron micrographs showing structure of an annealed and aged alloy specimen after fracture in $1367.2 \mathrm{hr}$ at $700^{\circ} \mathrm{F}$.

Longitudinal sections, near fracture; etched in a solution containing $25 \mathrm{ml}$ each of $\mathrm{HNO}_{3}$ glacial acetic acid,

$\mathrm{HCl}$ and water and $3 \mathrm{~g}$ of $\mathrm{NaOH}$; X 7,500. Arrows indicate $\mathrm{Ni}_{3} \mathrm{Al}$ precipitates at the triple points "a" and "b".

Electron microscopy replica techniques were used to ascertain more fully the size, number and distribution of the precipitates, subgrains, and strain markings in these specimens. The results are shown in figures 4 to 7 . Microstructures of the annealed and aged specimen tested at $700^{\circ} \mathrm{F}$ (fig. 4) indicated the presence of annealing twins (fig. 4A), well-defined subgrains, precipitates within some of the grains and an absence of them in other grains. It is probable that most were too small to be resolved at this magnification. Precipitates are also evident at the grain boundaries and appear to be largest at the triple points (fig. $4 \mathrm{Aa}$ and $\mathrm{Bb})$. Due to differences in structure of adjacent parent grains, the shape of the subgrains near the boundary is different from that in the interior of the grains (fig. $4 \mathrm{Bc}$ ). When the microstructures shown in figure 4 are compared with those of the cold-drawn and aged metal, shown in figure 5 , it appears that testing 


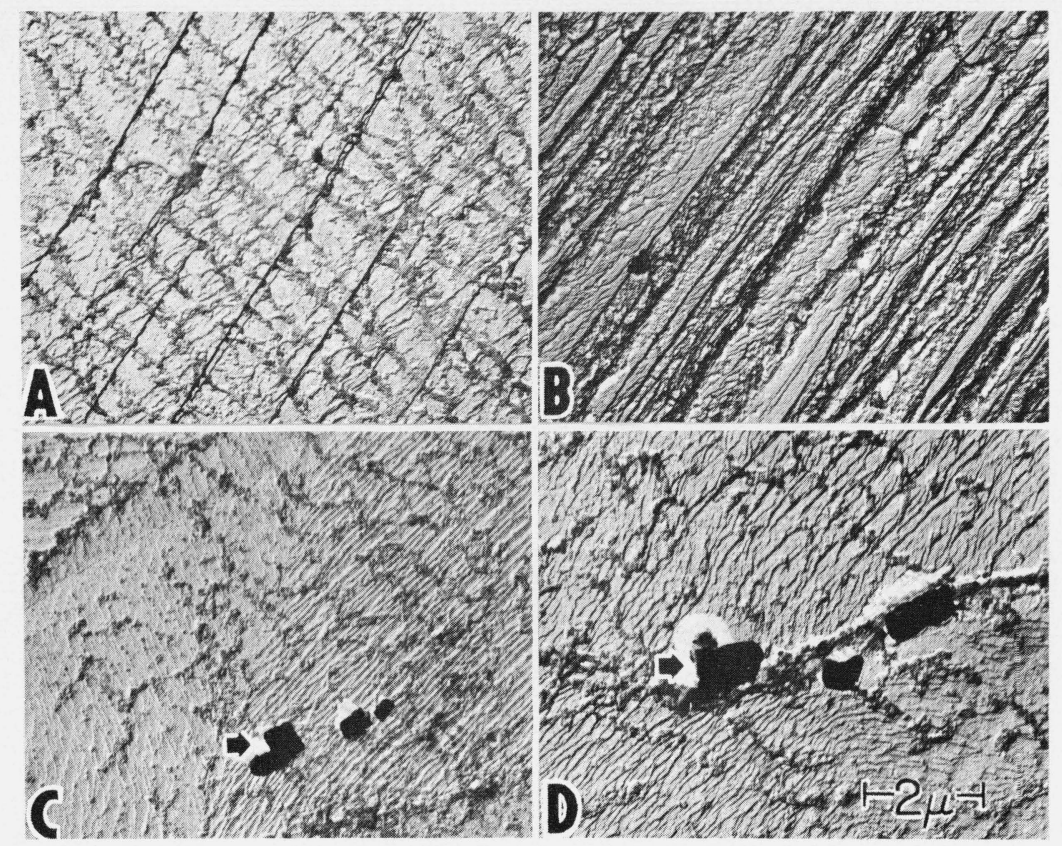

FiguRE 5. Electron micrographs showing structure of a cold-drawn and aged alloy specimen after fracture in $1068 \mathrm{hr}$ at $700^{\circ} \mathrm{F}$.

Logitudinal sections, near fracture; etched in a solution containing $25 \mathrm{ml}$ each of $\mathrm{HNO}_{3}$, glacial acetic acid, $\mathrm{HCl}$ and water and $3 \mathrm{~g}$ of $\mathrm{NaOH} ; \mathrm{X} 6,000$. Arrows indicate $\mathrm{Ni}_{3} \mathrm{Al}$ precipitates.
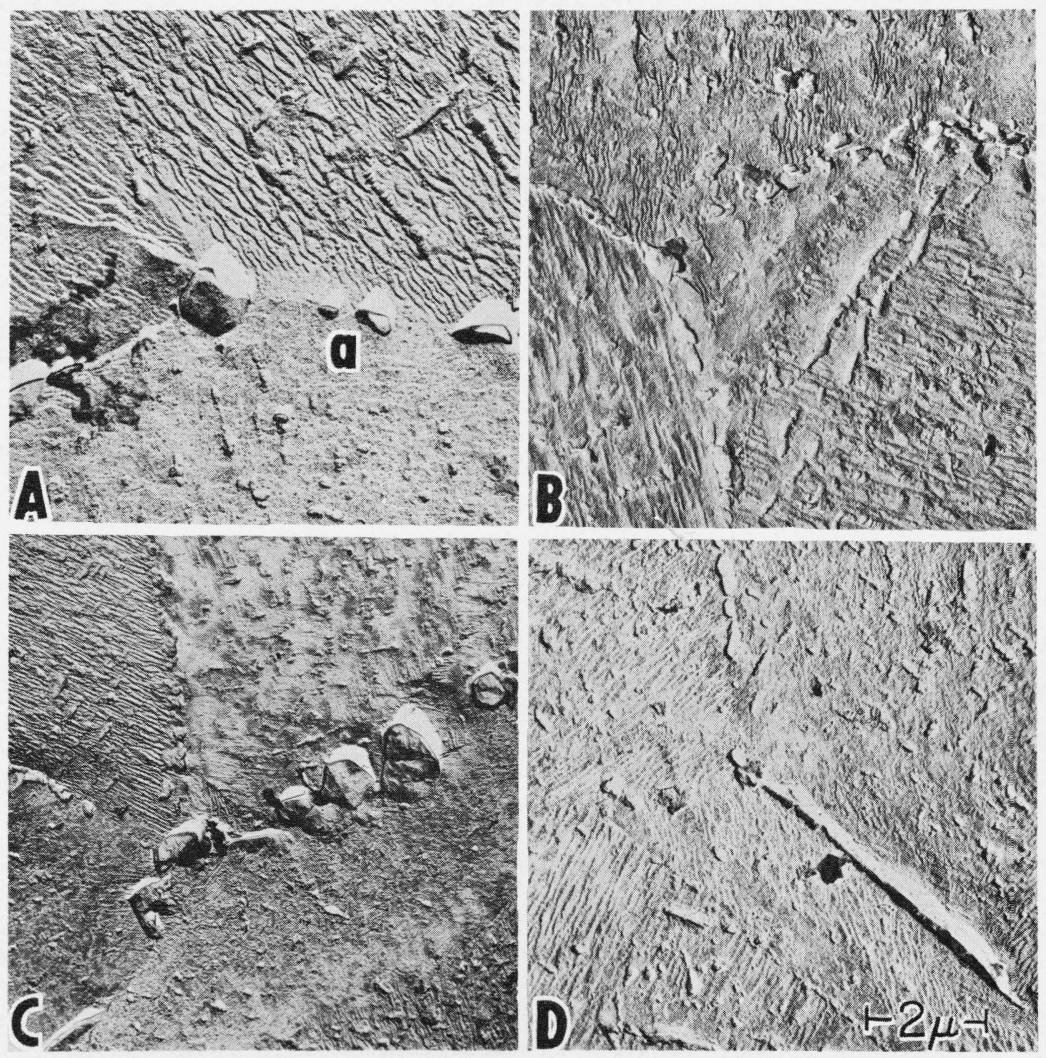

FIGURE 6. Electron micrographs showing structure of an annealed and aged alloy specimen after fracture in $2059.7 \mathrm{hr}$ at $1200^{\circ} \mathrm{F}$.

Longitudinal sections, near fracture; etched in a solution containing $25 \mathrm{ml}$ each of $\mathrm{HNO}_{3}$, glacial acetic acid, $\mathrm{HCl}$ ard water and $3 \mathrm{~g}$ of $\mathrm{NaOH} ; \mathrm{X} 6,000$. "a" indicates precipitate-free region near grain boundary. 


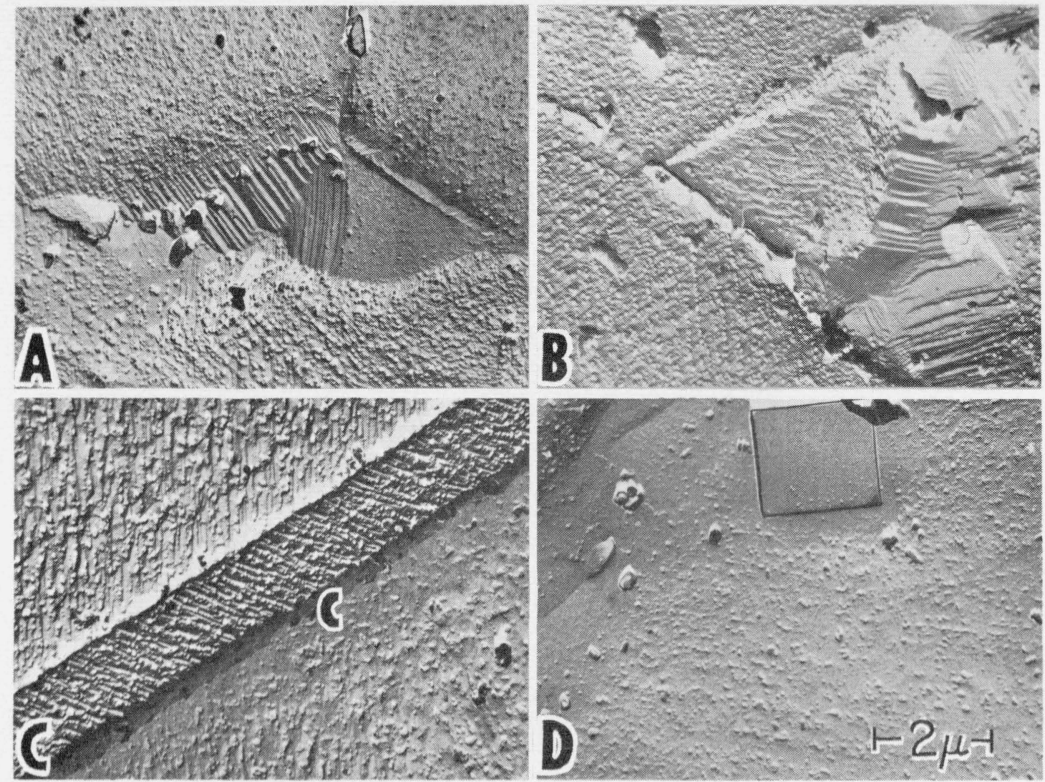

FigURE 7. Electron micrographs showing structure of a cold-drawn and aged Duranickel specimen after fracture in $2452.7 \mathrm{hr}$ at $1200^{\circ} \mathrm{F}$.

Logitudinal sections, near fracture; etched in a solution containing $25 \mathrm{ml}$ each of $\mathrm{HNO}_{3}$, glacial acetic acid, $\mathrm{HCl}$ and water and $3 \mathrm{~g}$ of $\mathrm{NaOH} ; \mathrm{X} 6,000$. "c" indicates precipitate-free region near twin boundary.

the aged metal at $700{ }^{\circ} \mathrm{F}$ increases the width of the subgrain boundaries (fig. 5A and C), the size of some of the precipitates (fig. 5C and D, arrows) and the number of slip bands (fig. 5B). The discontinuous nature of some of the strain markings is illustrated in figure 5A. The differences in microstructures had a marked effect on the creep behavior at $700{ }^{\circ} \mathrm{F}$ as indicated by the data in figures 8 to 11 .

In general, it was found that the size of the precipitates increased with increase in temperature and with increase in time. The size of the precipitates, observed in specimens tested at $1200{ }^{\circ} \mathrm{F}$, was less for the cold-drawn and aged (fig. 7) than for the annealed and aged specimens (fig. 6). Some areas adjacent to the grain boundaries (fig. 6Aa) or twin boundaries (fig. 7Cc) are comparatively free of precipitates. However, precipitation within the grains appears to have taken place on definite preferred planes and the size of these precipitates was less affected by cold-drawing than the size of those at the grain boundary. These differences in microstructures had little effect on the creep behavior at $1200{ }^{\circ} \mathrm{F}$ as indicated by figures 9 and 10 .

\section{Test Data and Discussion}

Davies, Richards, and Wilshire [3] studied the effect of prior cold-work on creep and fracture of a nickel-0.1 atomic percent gold alloy. They concluded that, below the recrystallization temperature, creep rate was reduced and rupture life was increased when the prestrain exceeded the initial strain. Their results were interpreted on the basis of varying contributions from the grain interiors and the grain boundary regions. Dennison and Wilshire [4] carried out tests on three grades of nickel and observed that decrease in purity was accompanied by an increase in creep resistance and rupture life. They concluded that impurities impeded grain boundary migration, caused a decrease in ductility and an increase in the occurrence of cracking. The effects of cold-drawing on creep of some nickel-copper alloys were discussed by Jenkins and Willard [5].

Strain-time curves for some of the creep specimens used in the present investigation are shown in figure 8 . Cold-drawing has reduced the extent (time and strain) of both the first and second stages of creep below the values for the annealed specimens, previously reported [2]. For the aged material the first stage was practically nonexistent. The shape of the curves are both temperature and stress dependent. Time lag before the initiation of plastic deformation at $1200{ }^{\circ} \mathrm{F}$ is believed to be due in part to the blocking of the motion of dislocations by the precipitates that formed at $1200{ }^{\circ} \mathrm{F}$ before loading the specimens. These precipitates have been shown both by $\mathrm{x}$-ray and electron diffraction to be predominantly particles of $\mathrm{Ni}_{3} \mathrm{Al}$. The properties of this compound have been studied extensively by Guard and Westbrook [6].

The relation between stress and second stage creep rate $^{3}$ is shown in figure 9. A linear relationship be-

${ }^{3}$ The second stage creep rates were obtained from strain-time curves when the data were plotted on a linear scale (not shown). 

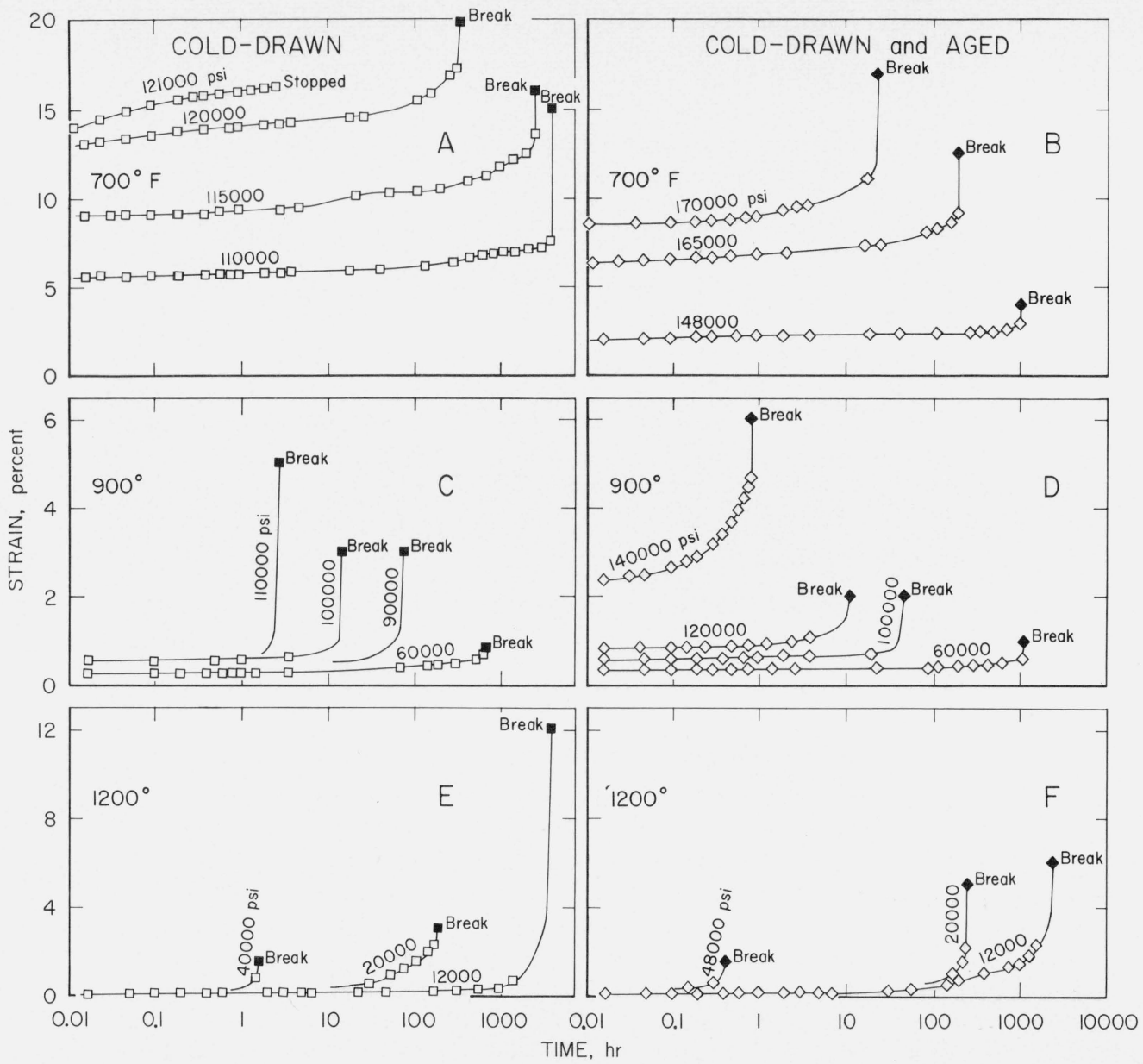

FIGURE 8. Strain-time relations of cold-drawn and cold-drawn and aged alloy specimens tested at different temperatures.

tween these variables was not obtained when the data were plotted on linear, log-log, or semilog coordinates. The sigmoidal form of some of the curves indicates the existence of a creep rate for which strain hardening is a maximum. Cold-drawing the metal increased the strength at 700 and $900{ }^{\circ} \mathrm{F}$ with the greatest increase occurring at the faster rates (fig. 9A). Furthermore, cold-drawing prior to aging improved the creep strength (fig. 9B) in comparison to the annealed and aged metal. No significant difference in strength is observed at $1200^{\circ} \mathrm{F}$ where recrystallization and overaging occurred during the tests.

The effect of stress on time to fracture is shown in figure 10. Obviously, no simple equation could be used to describe the relationship between these variables or between the family of curves for specimens having the same or different heat-treatments. It is observed, at 700 and $900{ }^{\circ} \mathrm{F}$, that strengthening due to cold-drawing or aging is less effective at the longer test times than at the shorter times. Recovery of the strained material is believed to be the major cause of this phenomenon. Although the stress-creep rate and stress-fracture time curves appear to be similar, no consistent relation existed between creep rates and fracture times for either the cold-drawn or cold-drawn and aged specimens.

The interrelationship between second stage creep rate and ductility is shown in figure 11. In general, elongation and reduction of area values increased with increase in creep rate at $700^{\circ} \mathrm{F}$ and decreased with increase in creep rate at $1200^{\circ} \mathrm{F}$. A large number of mechanisms, such as strain hardening, recovery, aging, transcrystalline and intercrystalline cracking, accompanied creep at $900{ }^{\circ} \mathrm{F}$ and caused the ductility values to vary in the same manner as was observed for annealed and annealed and aged Duranickel [2].

Rockwell hardness tests were made at room temperature on specimens after fracture to ascertain the effect of creep on hardening. Hardness indentations were made on cross sections of both the shoulder and on the deformed (reduced) section near fracture of the cold-drawn and cold-drawn and aged specimens in order to ascertain the effect of plastic deformation on aging characteristics. Small load-free control 


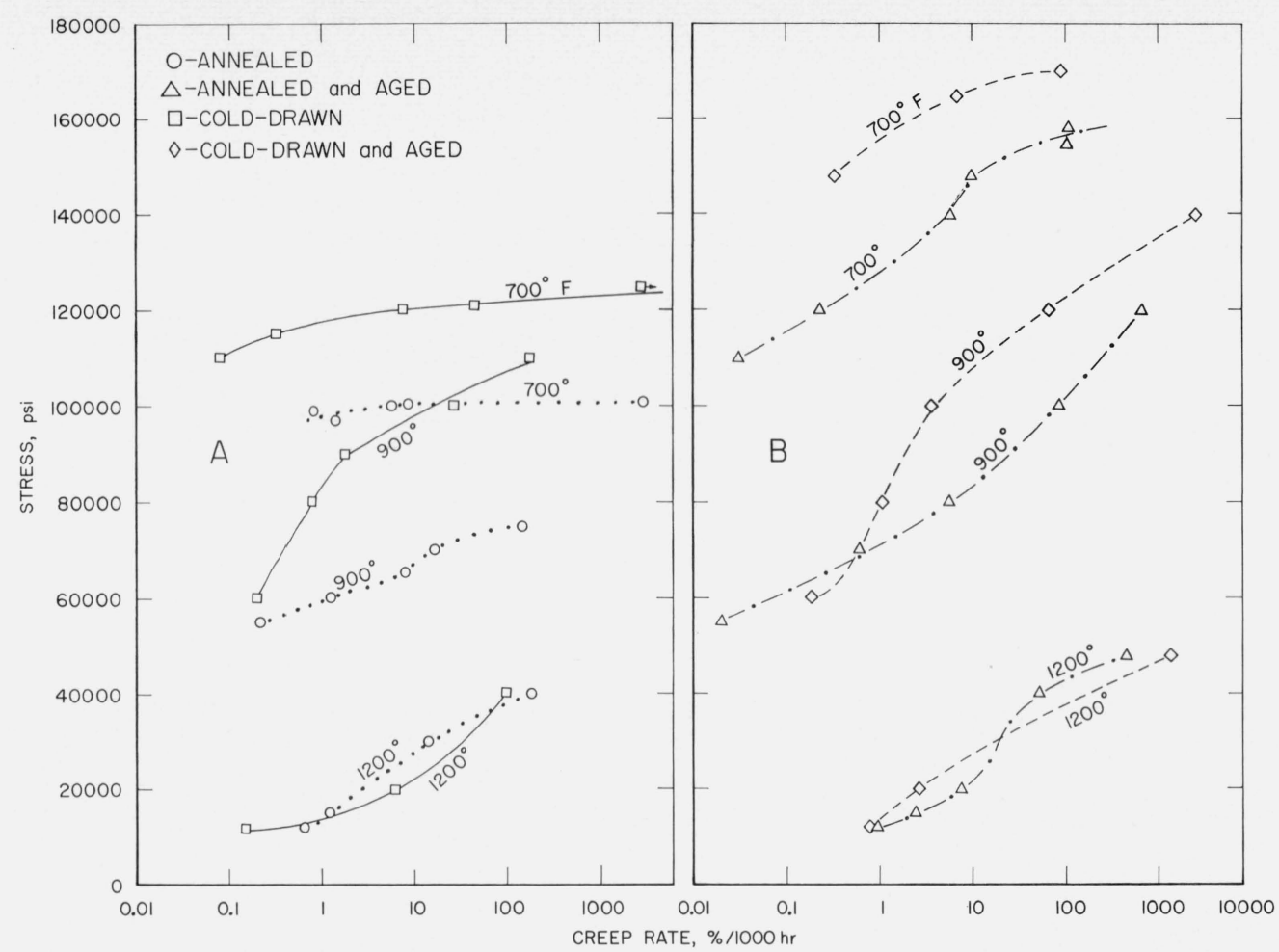

FigurE 9. Effect of cold-drawing and aging on the stress-second stage creep rate relations of the alloy.

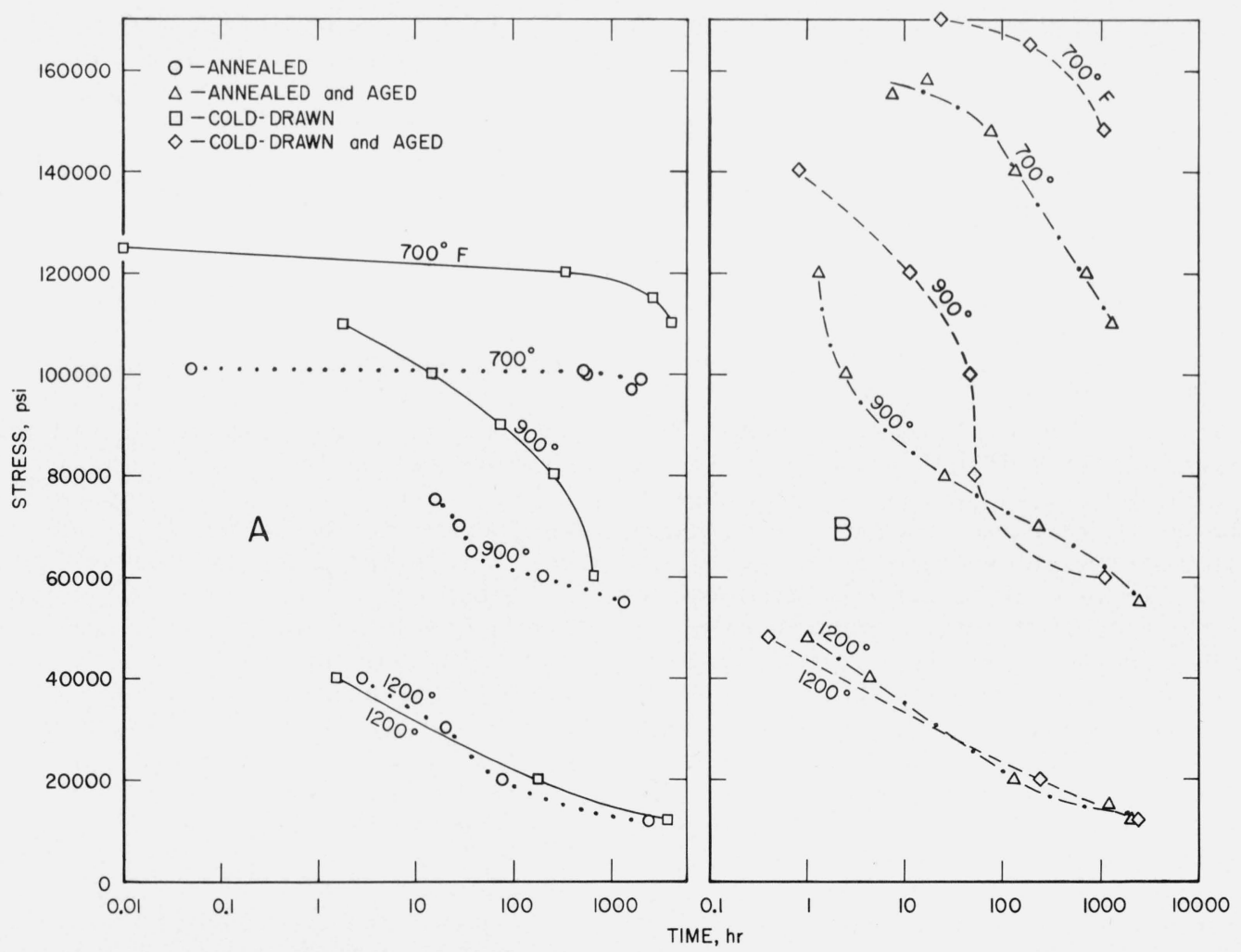

FIGURE 10. Effect of cold-drawing and aging on the stress-fracture time relations of the alloy. 


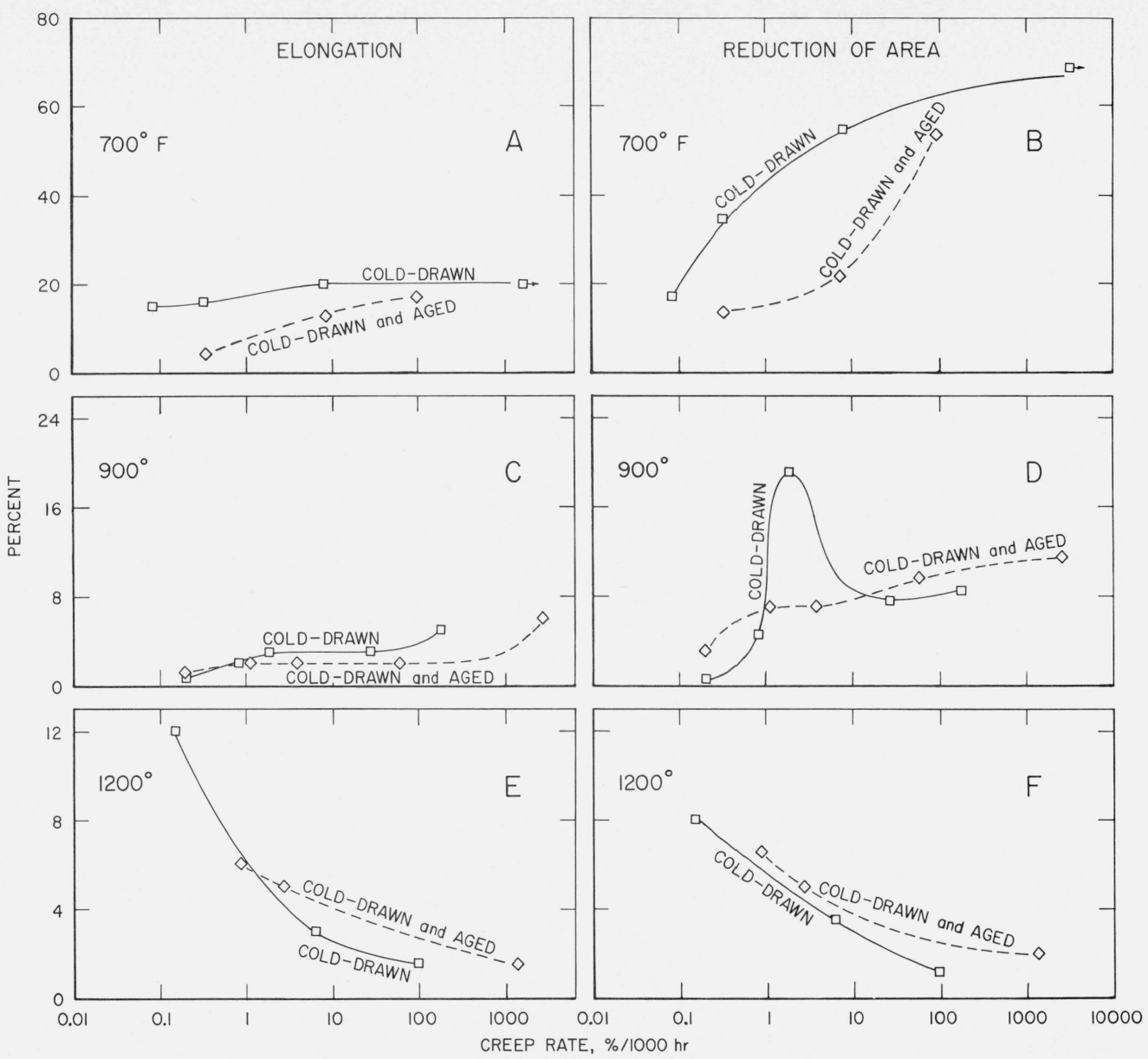

FIGURE 11. Influence of aging on the ducility-second stage creep rate relations of cold-drawn alloy specimens tested to fracture at different temperatures.

samples, heat-treated for times corresponding to the various fracture times in the creep tests, were tested for hardness and used for comparison purposes. As indicated by the hardness data for the cold-drawn specimens (fig. 12A, C, and E) precipitation-hardening was more predominant at 900 than at $700{ }^{\circ} \mathrm{F}$. This was evident for the specimens exposed to temperature only (fig. 12A), for unstrained portions of specimens (shoulders) exposed to temperature and stress (fig. 12C), and for the strained portions of the specimens (reduced sections) tested to fracture in creep (fig. 12E). Extensive recovery, recrystallization, and overaging occurred in the specimens tested at $1200{ }^{\circ} \mathrm{F}$ as shown by the decrease in hardness with increase in test time. This behavior was also evident for the cold-drawn and aged specimens (fig. 12B, $\mathrm{D}$, and F) tested at $1200{ }^{\circ} \mathrm{F}$; however, test time had only a slight effect on hardness values of the specimens tested to fracture at 700 and $900{ }^{\circ} \mathrm{F}$. These data tend to confirm the general trends associated with the hardness values obtained for the load-free specimens and shown in figure 1 .

\section{Summary}

Creep tests were made at temperatures of 700,900 , and $1200^{\circ} \mathrm{F}\left(644,755\right.$, and $\left.921^{\circ} \mathrm{K}\right)$ on a nickel-4.2 percent aluminum alloy initially as cold-drawn and as cold-drawn and age-hardened.

Microstructures and test data obtained in the present investigation are compared to results shown previously for the annealed, and annealed and aged alloy.

The hardness of the alloy was increased by colddrawing or aging. Additional hardening was induced by aging subsequent to the cold-drawing operation.

Due to the existence and formation of numerous barriers to the motion of dislocations through the crystal lattice, cold-drawing and aging increased the creep strength and decreased the ductility of the alloy at 700 and $900{ }^{\circ} \mathrm{F}$. No significant effect was apparent at $1200{ }^{\circ} \mathrm{F}$, which is slightly above the recrystallization temperature.

Elongation and reduction of area values increased with increase in creep rate at $700^{\circ} \mathrm{F}$ and with decrease in creep rate at $1200^{\circ} \mathrm{F}$. 


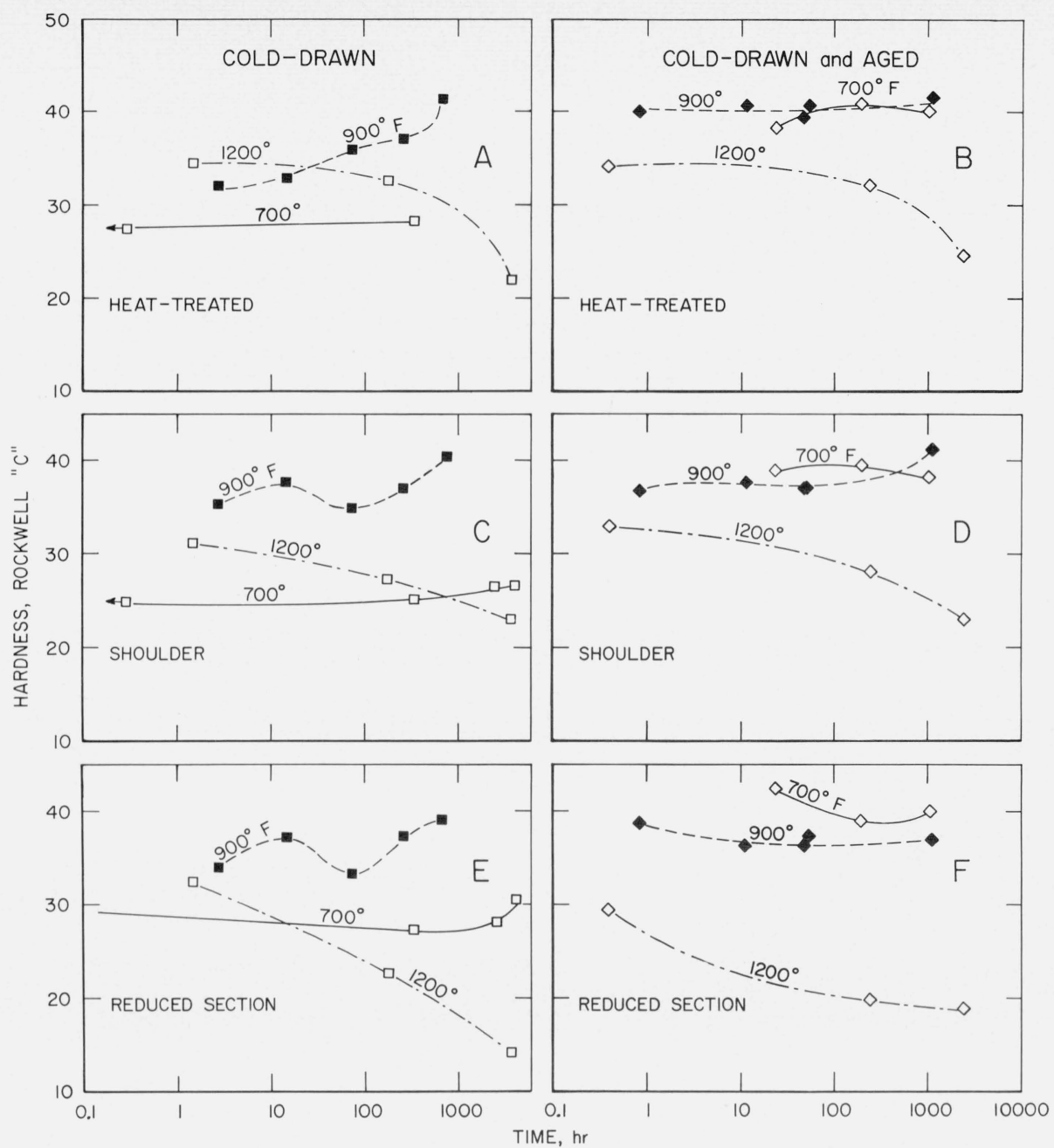

FIGURE 12. Effect of test temperature and time on hardness, at room temperature, of cold-drawn and cold-drawn and aged alloy specimens.

A, B, load-free control specimens as heat-treated; C, D, E, F, creep specimens after fracture.

Aging the cold-drawn alloy made it more ductile at $1200^{\circ} \mathrm{F}$ and less at $700{ }^{\circ} \mathrm{F}$.

Post-test hardness values decreased with increase in test time at $1200{ }^{\circ} \mathrm{F}$, due to recrystallization. With few exceptions, the hardness after testing at $900^{\circ} \mathrm{F}$ was equal to or greater than that after testing at $700^{\circ} \mathrm{F}$.

The tendency toward intercrystalline cracking increased with increase in test temperature. The number of cracks was increased by cold-drawing prior to age-hardening.

Microstructures, associated with high strength and ductility at the lower temperatures indicated the existence of small precipitated particles, small subgrains and rather straight intersecting and nonintersecting strain markings. However, at $1200{ }^{\circ} \mathrm{F}$, few markings were evident and coalesced precipitates appeared predominantly in the grain boundaries. The shape and number of the precipitates appeared to depend on where they are located in the crystal lattice.

(Paper 70C3-231)
The authors gratefully acknowledge the cooperation of James Heywood and David Ballard in carrying out the electron microscopic examination of the specimens.

\section{References}

[1] W. D. Jenkins and W. A. Willard, The temperature dependence of flow and fracture characteristics of an age-hardenable alloy, Trans. ASM 55, 580 (1962).

[2] W. D. Jenkins and W. A. Willard, Some factors affecting the creep behavior of an age-hardenable nickel alloy, Trans. ASM 56, 427 (1963).

[3] P. W. Davies, J. D. Richards, and B. Wilshire, The influence of cold-work on the creep and fracture behavior of a dilute nickel alloy, J. Inst. of Metals 90, 431 (July 1962).

[4] C. J. P. Dennison and B. Wilshire, Observations on the influence of impurities on the creep and fracture behavior of nickel at 500 and $600{ }^{\circ} \mathrm{C}$. J. Inst. of Metals 91, 343 (June 1963).

[5] W. D. Jenkins and W. A. Willard, Creep of cold-drawn nickel, copper, $70 \%$ nickel-30\% copper and 30\% nickel-70\% copper alloys, J. Res. NBS 66C (Phys. and Chem.) No. 1, 59 (1962).

[6] R. W. Guard and J. H. Westbrook, Studies of the compound $\mathrm{Ni}_{3} \mathrm{Al}$ by high-temperature X-ray methods, Trans. of the Metallurgical Soc. of AIME 215, 871 (1959). 